\title{
Variation between some apricot varieties in regard to flowering phenology in Boldogkőváralja, Hungary
}

\author{
Ezzat, A. ${ }^{1}$, Amriskó, L. ${ }^{2}$, Balázs, G. ${ }^{3}$, Mikita, T. ${ }^{2}$, Nyéki, J. ${ }^{1}$, \\ Soltész, M. ${ }^{1}$ \& Szabó, Z. ${ }^{1}$ \\ ${ }^{1}$ University of Debrecen, Institute of Horticulture, Email: ezzat_eg2003@yahoo.com \\ 4032 Debrecen, Böszörményi út 138. \\ ${ }^{2}$ NORTHCOT Ltd, 3885 Boldogköváralja \\ ${ }^{3}$ GYÜMÖLCSÉRT Ltd, 3885 Boldogköváralja
}

\begin{abstract}
Summary: the aim of this study was the estimation of blossoming of 14 apricot cultivars in Boldogkőváralja in 2009,2010 and 2011 seasons. And this will help growers to select appropriate varieties to their weather conditions. For this target the blooming period of 19 apricot varieties of different origin was observed in three subsequent years. There was no large difference in the beginning of blooming in the different years, and the greatest variation between the start date of flowering was about 1 to 3 days as the place of experiment site near to northern border and also, length of flowering period of apricot trees is also inversely related to date when blooming started. The little differences in flowering dates and flowering periods due to the high temperature through the three seasons of study.
\end{abstract}

Key words: apricot phenology, blooming and flowering period

\section{Introduction}

Phenology data are sensitive data to identify how plants are adapted to local climate and how they respond to climatic changes. Modeling flowering phenology allows us to identify the meteorological variables determining the reproductive cycle. Phenology of temperate of woody plants is assumed to be locally adapted to climate. Nevertheless, recent research shows that local adaptation may not be an important constraint in predicting phonological responses.

Plant phenology is very sensitive to climatic conditions and plays an important role in plant adaptation to climate (Gebler et al. 2007). Modeling plant phenology using climatic variables became an important issue in recent years, given the impacts of the climate change on plant phenology (Hanninen 1990; Chuine et al. 2000; Galán et al. 2005)

Many studies have shown that temperature increase is responsible for important changes in plant and animal phenology, such as advance of spring events and delay of autumn events (Menzel et al. 2006) Although it is generally assumed that the phenology of woody plants growing in temperate climate may adapt to different local climate conditions, local adaptation depends on a balance between natural selection and gene flow and will occur if the natural selection processes prevail (Lenormand 2002). When local adaptation exists, phonological models should be fitted for each population in order to obtain more accurate predictions, since the phonological response of various plant populations to climate is different. Recent studies on deciduous trees from northern Europe showed that local adaptation may not be an important constraint in predicting phenology at the species level (Chuine et al. 2000). However, the role of genetic differentiation in plant phenological response should be determined for each species whenever possible, in order to ensure the accurate model predictions at the species level, especially if the species is a cultivated one and the local varieties were selected.

Temperature during winter and early spring season are the major factors affected the blooming of apricot tree (Szalay and Szabó 1999). Flower buds can be often frozen during winter frost periods, flowers and young fruit can be also injured in frost days in April and as the results of this, no yield will be obtained (Jakubowski 1988, Krska 1993). The problem how to avoid or minimise the risk connected with weather conditions is still important to be solved in many countries, because that is the only possibility to increase interest of apricot production.

The aim of this study was the estimation of blossoming of 14 apricot cultivars in Boldogkőváralja in 2009, 2010 and 2011 seasons. And this will help growers to select appropriate varieties to their weather conditions.

\section{Materials and methods}

About 10 years old trees of several apricot cultivars were planted on the Myrobolan rootstock seedling, the experiment was established in Boldogkőváralja. First part of the experiment was carried out by randomized block design, in five replications with four trees on each plot. All agro- 
technical methods used in whole experiment were carried out like in apricot commercial orchard and plant protection according to current recommendation of Orchard Protection Programme.

Beginning of blooming period of 14 apricot cultivars were observed on each tree separately, from 2009 to 2011. The estimation was based on the visual observation average three times a year.

Terms of appearance and length of following phenological phases were studied:

\begin{tabular}{|l|l|l|}
\hline \multicolumn{1}{|c|}{ Phenophase } & \multicolumn{1}{|c|}{ Criterium } & \multicolumn{1}{c|}{ References } \\
\hline Start of bloom & $\begin{array}{l}1-5 \% \text { of flowers } \\
\text { opened }\end{array}$ & Soltesz (1992) \\
\hline Full bloom & $\begin{array}{l}50 \% \text { or more flowers } \\
\text { opened }\end{array}$ & $\begin{array}{l}\text { Nyeki (1980. 2002) } \\
\text { Soltesz (1982) }\end{array}$ \\
\hline End of bloom & 50\% of petals dropped & $\begin{array}{l}\text { Blasse and Hofmann } \\
\text { (1992) }\end{array}$ \\
\hline
\end{tabular}

\section{Results and discussion}

The bloom period comprises the phase of start, main and end of blooming. The easiest to determine is the start. According to date in fig. 1,2 and 3. we can divide all tested varieties according to their phonological parameters to 2

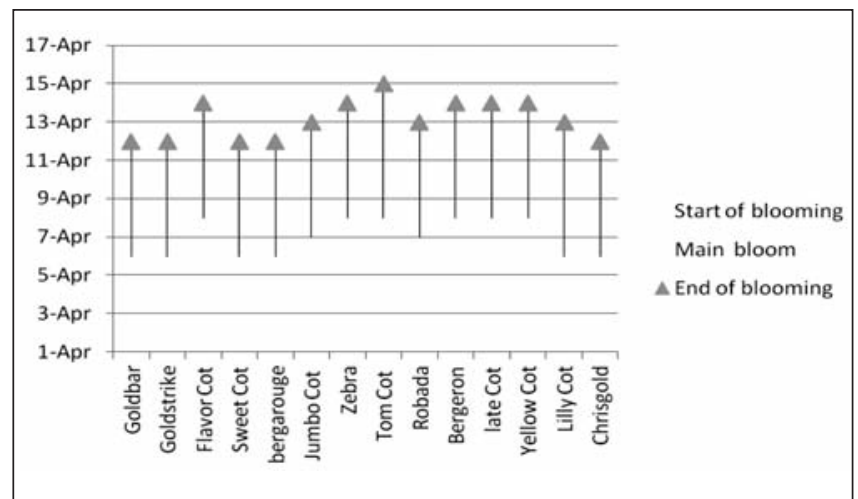

Fig 1: Time of start, main and end of blooming 14 apricot varieties through 2009 seasons.

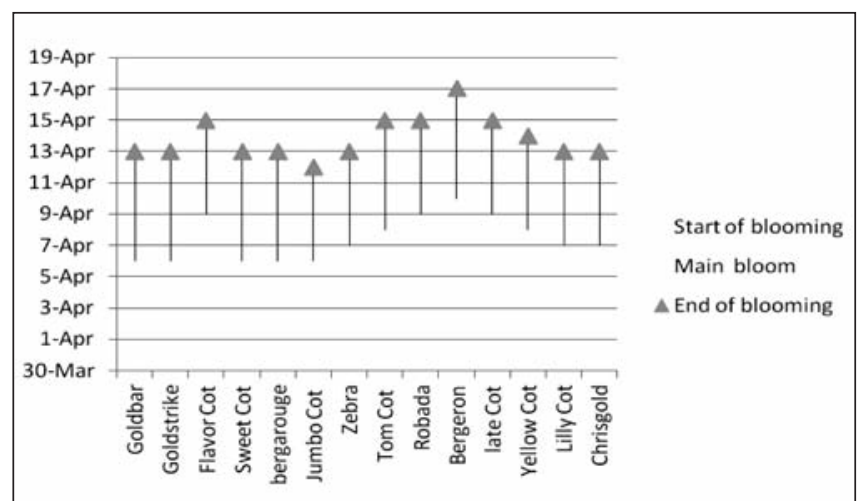

Fig 2: Time of start, main and end of blooming 14 apricot varieties through 2010 seasons sections: First: varieties which flower early (Goldbar, Goldstrike, Sweet cot, Bergarouge. Jumbo Cot, Lilly Cot and Chrisgold) Second: varieties which flower late (Flavor Cot, Zebra, Tom Cot, Robada, Bergeron, Late cot, Yellow Cot). Also we can notice that the differences between all varieties is about 1 to 3 days according to start of flowering and this may be due to on the northern border of apricot cultivation, there is but little difference in blooming date of varieties. Actually, the delays between earliest and latest varieties grown shows 4-5 days differences. A higher number of varieties and cold spring weather may produce some differences of 8-12 days ((Nyuitó, 1980 Pedric, 1992). The delay between the first and last blooming varieties depends on the date of beginning of blooming. The earlier the date of start, the longer the delay between varieties and already this cannot be noticed in this experiment as the differences between the dates of beginning of flowering is about 1 to 3 days. Within the variety group of Magyar kajszi, Nyuito (1980) observed differences of 3 to 12 days in the start of flowering, whereas Vachun (1983) stated 1-3 day differences between clones of Velkapavlovicka variety.

The figure (4) shows length of flowering period of apricot trees is also inversely related to date when blooming started. As an example, 6 to 9 days between the start and the end of blooming and this is related with the finding of (Nyuitó, 1980). Also, Suranyi and Molnar, 1981 found that Magyar kajszi finished blooming within 6-7 days at $20^{\circ} \mathrm{C}$, whereas

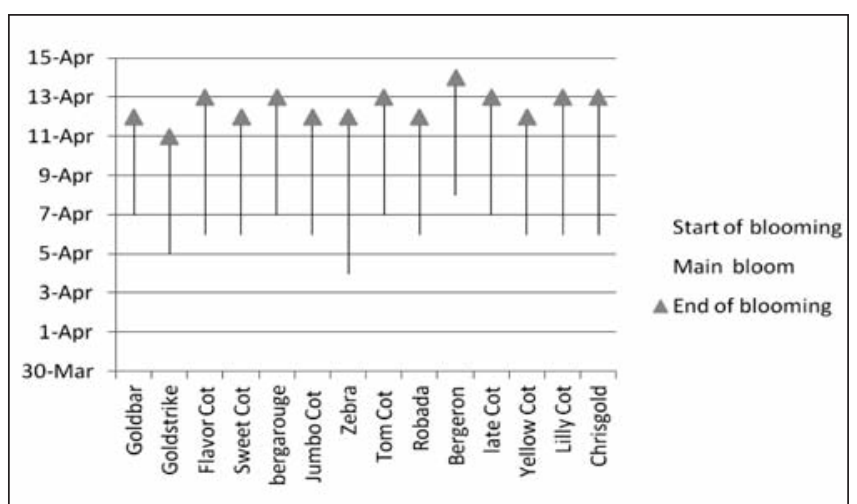

Fig 3: Time of start, main and end of blooming 14 apricot varieties through 2011 seasons

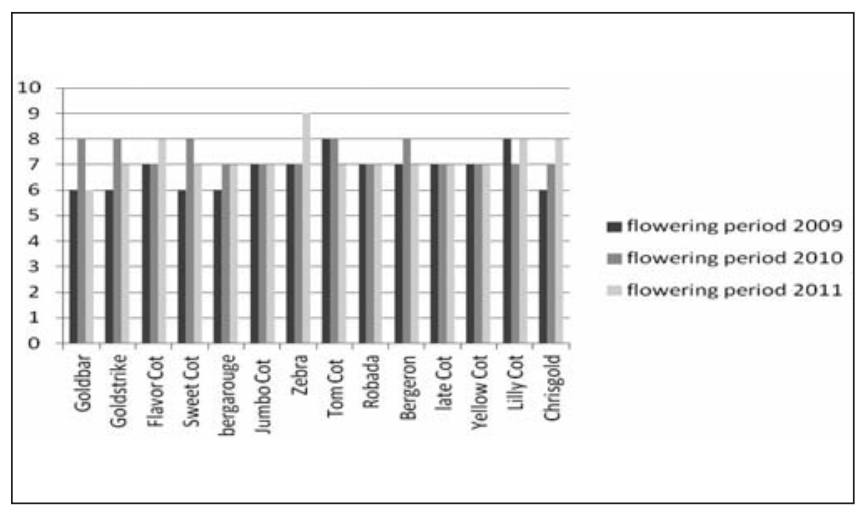

Fig. 4: Flowering periods 14 apricot varieties through 2009, 2010 and 2011 seasons 
8-11 days at $15-20{ }^{\circ} \mathrm{C}$, but $11-16$ days at $12-17{ }^{\circ} \mathrm{C}$. This may help us to understand the difference trend of one variety through 3 seasons of study as it depended on the temperature as the flowering period will be longer in cool weather than at higher temperature as Szalay and Szabo (1999) registered the blooming period of 20 apricot varieties at higher temperature the period lasted 5 to 7 days meanwhile lasted 14 to 21 days in cool weather. The sequence of varieties may change according to the season. Also, in our data there are no big differences in flowering period as there are no obvious differences in times of start, main and end of flowering.

\section{Conclusion}

This study may indicate that the varieties take different trends in flowering dates and this is according to the place and the weather so, we have to do long time research to get good classification to our varieties.

\section{Acknowledgement}

Research was sponsored by NFÜ TECH-08-A3/2-20080373 grant.

\section{References}

Chuine, I., Belmonte, J., Mignot, A. (2000): A modelling analysis of the genetic variation of phenology between tree populations. J Ecol 80: 561-570.

Galán, C., García-Mozo, H., Vázquez, L., Ruiz, L., Díaz de la Guardia, C., Trigo, MM. (2005): Heat requirement for the onset of the Olea europaea L. pollen season in several sites in Andalusia and the effect of the expected future climate change. Int J Biometeorol 49:184-188.
Gebler, A., Keitel, C., Kreuzwieser, J., Matyssek, R., Seiler, W., Rennenberg, H. (2007): Potential risks for European beech (Fagus sylvatica $\mathrm{L}$.) in a changing climate. Trees, 21 (1): 1-11.

Hanninen, H. (1990): Modelling bud dormancy release in trees from cool and temperate regions. Acta Forest Fenn, 213: 1-47.

Nyéki, J. (1989): Blooming and fertilization of stone fruits. (Hungarian). Mezőgazdasági Kiadó, Budapest

Nyéki, J. (2002): Blooming, fertilization, and the association of cultivars in plantations. (Hungarian). Mezőgazdasági Kiadó, Budapest

Nyujtó, F. (1980): (The Apricot) (Hungarian). [In: Nyéki, J. (ed): Floral biology and fertilization in fruit varieties.] Mezőgazdasági Kiadó, Budapest, 148-266.

Menzel, A., Tim, H., Sparks, T., Estrella, N., Koch, E., Aasa, A., Ahas, R., Alm-Kübler, K., Bissolli, P., Braslavská, O., Briede, A., Chmielewski, FM., Crepinsek, Z., Curnel, Y., Ahl, Å., Defila, C., Donnelly, A., Filella, Y., Jatczak, K., Måge, F., Mestre, A., Nordli, Ø., Peñuelas, J., Pirinen, P., Remišová, V., Scheifinger, H., Striz, M., Susnik, A., Van Vliet, AJH., Wielgolaski, F., Zach, S., Zust, A. (2006): European phonological response to climate change matches the warming pattern. Glob. Chang. Biol, 12 (10): 1969-1976.

Pedric, A. (1992): Variability of some properties in apricot with relevance to breeding (Hungarian). Thesis for the Hungarian Acad. Sci., Budapest

Szalay, L. and Szabó, Z. (1999): Blooming time of several apricot varieties. Int. J. Hort. Sci., 5 (1-2): 16-20.

Szabó, Z. and Nyéki, J. (1992): Blossoming, fructification and combination of apricot varieties. Acta Horticulturea, 293: 311-318.

Vachun, L. (1981): Etude de quelques properietees morphologiiques et physiologiques du pollen $\mathrm{d}$ abricotier, germination et croissance des tubes polliniques a basses temberatures. Acta Horticultuae, 85: 387-417.

Surányi, D. and Molnár, L. (1981): Physiology of apricot tree (Hungarian). [In: Nyujto F and Surayi D.: Apricot] Mezőgazdasági Kiadó, Budapest, 177-214. 